\title{
DETERIORATION MECHANISMS AFFECTING THE BRICKS USED IN THE BUILDING OF THE WATER WELLS AT KARNAK TEMPLES, LUXOR, EGYPT
}

\author{
El-Badry, A. \\ Conservation Lab. Manger, ARCE, Karnak, Luxor, Egypt \\ E-mail: hakimelbadry@yahoo.com
}

\begin{abstract}
The water wells at Karnak temples made of red brick and belonging to different eras, (GraecoRoman and Byzantine periods). These water wells suffer from several deterioration aspects such as exfoliation, hard crusts, disintegration, spalling, cracks, fractures, salts crystallization, microorganisms colonization's and vegetation. The aim of this paper is to study the deterioration mechanisms affecting the brick units of these wells to prepare a conservation strategy. Different scientific methods such as Light Optical Microscope (LOM), Polarizing Microscope (PM), Scanning Electron Microscope coupled with an Energy Dispersive X-Ray Spectrometer (SEM-EDX) and $X$-Ray Powder Diffraction (XRD) have been used to determine the mineralogical composition and the deterioration products. The obtained results have proved that the water wells suffer from salts crystallization of sodium chloride and sodium sulfate (thenardite) due to the severe effects of deterioration factors particularly the dominated environmental conditions, water-soluble salts and mineralogical composition of the brick.
\end{abstract}

Keywords: Brick, Water wells, Karnak temples, Deterioration, Salts, Thenardite, Halite

\section{Introduction}

The recent excavations carried out by the Supreme Council of Antiquities (SCA) in front of the first Pylon of Karnak temple, near to the tribune have revealed group of water wells made of red brick adjacent to the large harbor and in El-madrassa site (the southern part of the site). Also, there are many water wells located inside Karnak temples [1], which were results of the previous excavations such as; those in front of the main entrance (gate) of the temple, open museum, and in the southern façade of ninth pylon, fig. (1-a,b,c). The previous archaeological studies just dated these water wells back to the late Ptolemaic, Roman or Byzantine periods without more detailed extensive study for these wells [2]. There were many fun- ctions of water wells in ancient Egypt that; they can ameliorate the amount of water and the quality of available of the drinking water, irrigation the plants, providing water for the animals, or the supply of workshops and settlements with water. Furthermore, the construction of wells in temples, is being architectonic scenery for cultic events [3,4]. The function of water wells at Karnak temples is that; they supplied the houses and workshops attached to the temple with water, the area located southwestward of the first pylon was used in the late Ptolemaic \& Roman periods for residence, and there were some industrial workshops and settlements [5]. The depths of these wells varying greatly from one to another, because many of these wells still covered 
and buried under soil. There were several methods for building in ancient Egypt and from the field observation we conclude that, the building method used in construction the water wells at Karnak temples is the Egyptian bond (English bond), fig. (1-d), the bonding on the faces of those walls shows alternate layers of headers and stretchers [6] different sizes of red brick employed in construction of those water wells and the almost brick's dimensions are $28 \times 14 \times 6 \mathrm{~cm}$. So that, the red brick dimensions vary according to the geographical area, the historical period [7] and the construction type also. According to [8] the mortar used in these wells was lime mortar. That mortar was suitable for use in damp places, since it is impermeable to water and is found in Ptolemaic and Roman fired-brick structures, especially baths and conduits, where it was necessary to make the joints waterproof. During the Graeco-Roman and Byzantine

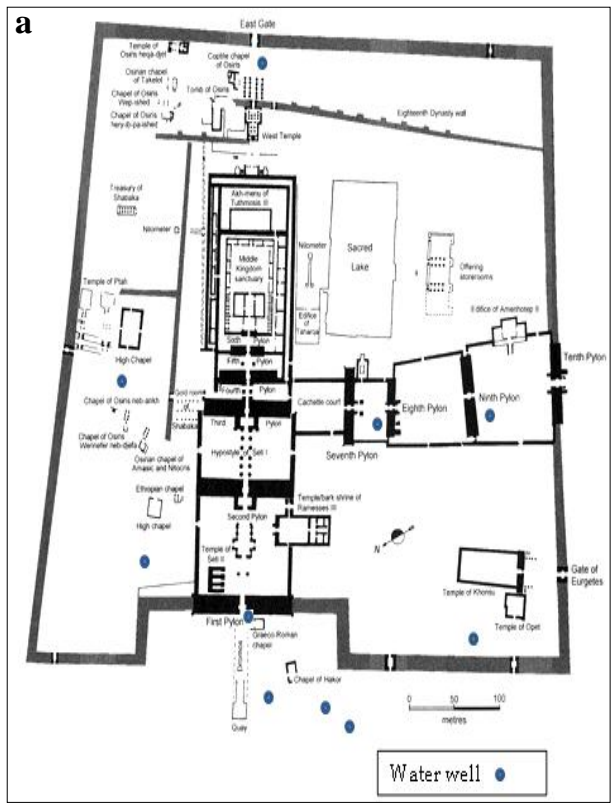

periods the builders and architects used red brick in domestic architecture in locations exposed to humidity such as; underground constructions as water wells, cisterns, baths, thresholds, and conduits [8]. The evidence for manufacturing bricks in ancient Egypt comes from the themes in the tomb of the prince Rekh-mi-Re at Thebes [9]. The materials used in making bricks in ancient Egypt were various and contained both inorganic and organic materials mainly Nile clay, sand, lime, different aggregates and animals dung as well as chopped straw (hay) as binding materials. In addition to the existence of pottery and stones fragments which were added during making process to increase the mechanical properties [10]. So the mechanical and chemical properties of resulting brick varied greatly depending on the locality and the time according to sedimentary provences, extension and by their chemical and physical properties [11].

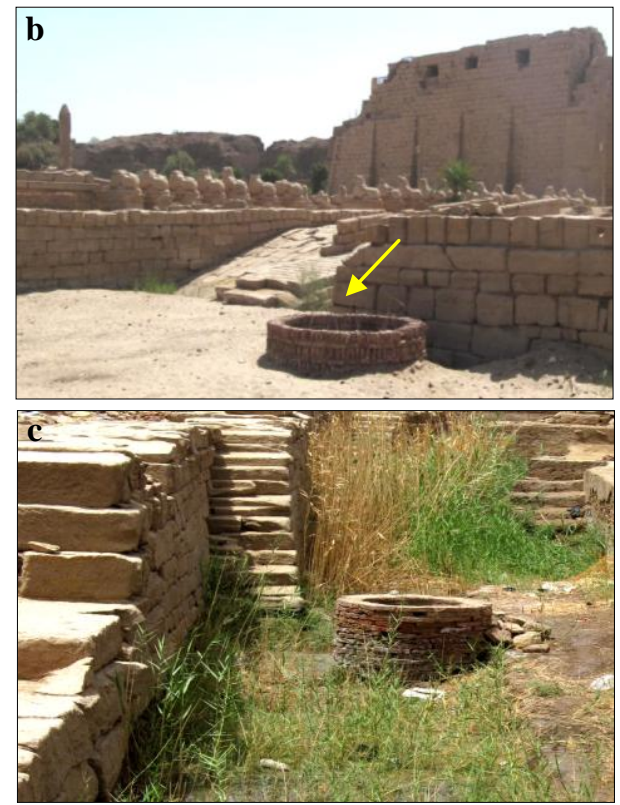

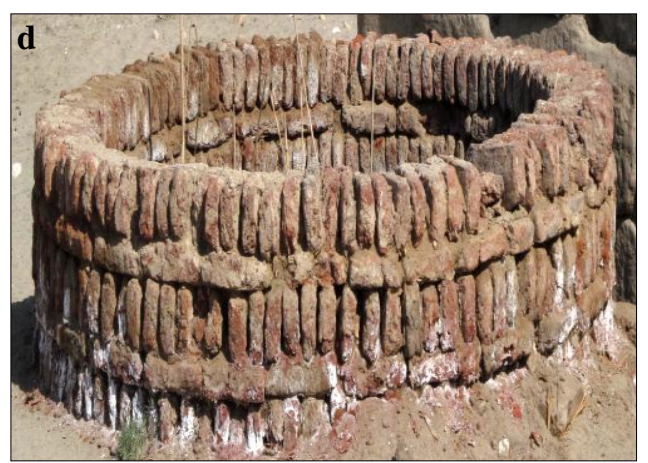

Figure (1) Shows a. location of water wells inside Karnak temples complex (after Blyth, 2006 \& CNRS 2019), $\underline{\mathbf{b}}$. well in the front of the first pylon of Karnak, $\underline{\mathbf{c}}$. well close to embankment at Elmadrassa site, $\underline{\mathbf{d}}$. building methods of water wells at Karnak temples 


\section{Deterioration State}

Field observation for water wells at Karnak temples has proved that, the bricks had been exposed to either burial and aerial environments so the bricks become very weak and losing cohesion among their components because of its exposition to many deterioration factors such as; extreme temperature, solar radiation, moisture variation, saline solutions, atmospheric gases, and microorganisms effects in addition to the intrinsic physical properties, mineralogical composition of the raw materials and firing temperature of the bricks [12], in addition to other parameters that include the composition of the mortar, and the properties of the masonry unit/mortar combination [13]. All these conditions play an important role in the deterioration aspects such as; changes in chemical and physical compositions of the bricks especially when buried in a salty ground. In addition to exfoliation [14] and formation hard crusts due to crystallization of salts under
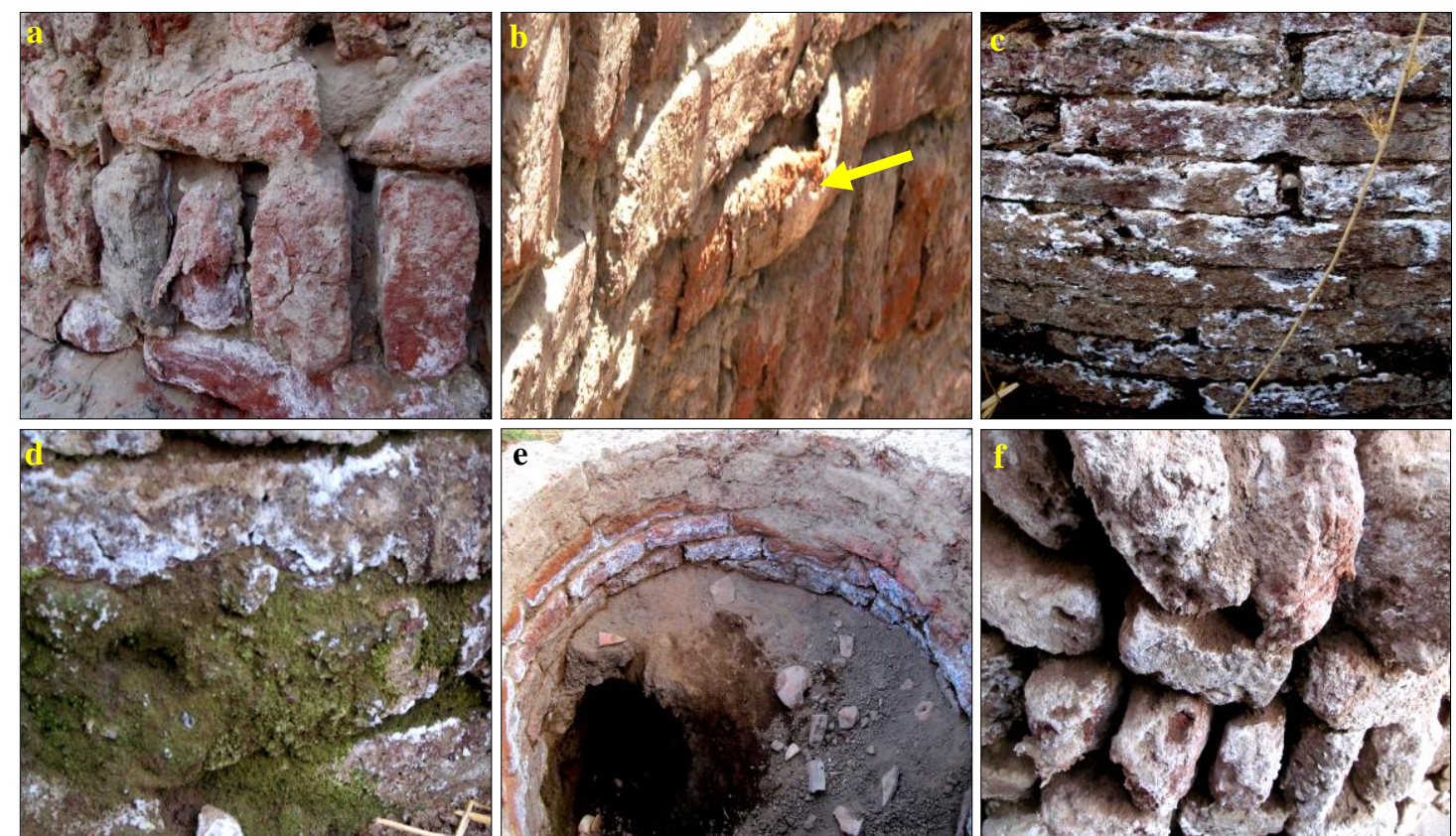

Figure (2) Shows deterioration features of water wells at Karnak temple a. exfoliation, $\underline{\mathbf{b}}$. crumbling,

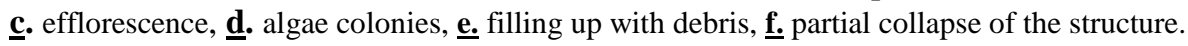

\section{Materials and Methods}

Small weathered samples of brick were studied utilizing the scientific techniques; light optical microscope (LOM) (Olympus SZ61 with Olympus E-330 digital camera), polarizing microscope sub-strata, disintegration, spalling, cracks and fractures. Also, moisture penetration along these cracks or pore passageways causes the severe damage for the red bricks and the mortar [15]. Other deterioration aspects are represented such as the action of biological colonies [16] and vegetation. The damage and collapsing of the architectural features or destruction some parts of the construction were observed in some wells due to deposits press before excavation. All these deterioration phenomena caused decohesion and weakness of the structure and texture of wells and brick units also loss of the binding mortar used in construction process as shown in, fig. $(2-a, b, c, d, e, f)$. The aim of this article is to study the deterioration mechanisms of the brick units used in building of these wells and to prepare a conservation plan. 
used to identify the mineralogical composition and the deterioration products of the brick. It was adapted according to El-Midany \& Mahmoud., 2015 [17] and Cultrone, et al., 2005 [18] using the foll- owing parameters; diffractometer type Philips PW 1840, operated at $35 \mathrm{kV}$, using a $\mathrm{Cu} \mathrm{K}^{\alpha}$ radiation wavelength of $1.540598 \AA$

\section{Results}

\subsection{Visual examination of hand specimens}

A scientific digital camera was used for determining the visual features of brick samples especially the texture and color; the images of red brick samples, fig. $(3-a, b)$ have illustrated different colors

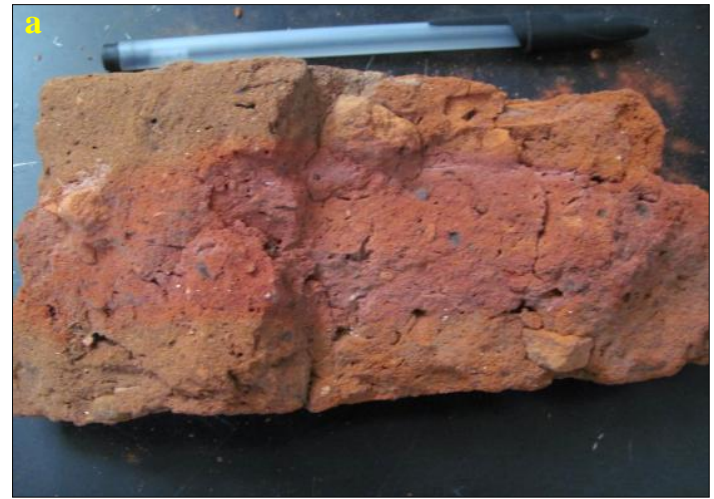

Figure (3-a, b) Shows different colors and texture features of the red brick samples collected from Karnak temple wells

\subsection{Optical properties of the samples by LOM}

Light Optical Microscope (LOM) images of brick samples, fig. (4-a,b,c,d), have illustrated that, the brick contains different components such as; pottery shreds, limestone and red brick fragments, moreover organic materials such as; cho-
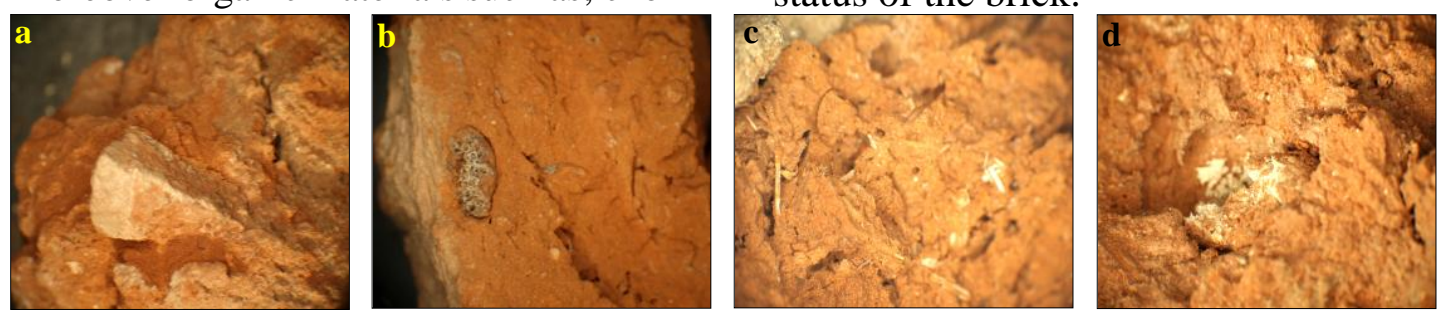

Figure (4) Shows micrographs of investigated red brick samples by LOM (4-X) a. pottery fragments,

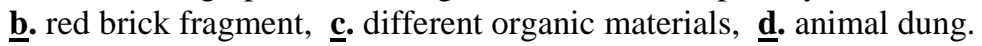

\subsection{Petrographical characteristics of the samples by PM}

The Petrographical study by polarizing microscope (PM) was carried out for the concerned red bricks, which illustrates that, the brick samples from water wells at Karnak temples, fig. (5a,b,c,d,e,f) illustrates that, the brick is mainly composed of quartz, feldspar, mica, allanite, zircon, iron oxide and rock debris as original constituents. Sericite, chlorite and epidote are secondary constituents due to many alteration processes. Pottery fragments and chopped straw as an additional constituent. Quartz grains or free crystalline silica, varied in size, shape, mainly angular to sub-angular in rich ground of iron oxides and clay minerals mixture, fig. (5-a). Feldspars minerals also are represented as one of the main 
components in the brick samples. They are as plagioclase (albite) and alkali feldspars (microcline); plagioclase crystals occur as subhedral to anhedral, characterized with twin lamination, turbid, cracked and commonly stained by iron oxides and enclosed with iron oxides granules, which gives it a brown pigmentation due to the intensive alteration. Microcline crystals appeared as subhedral to anhedral, characterized by cross hatch twinning. Some samples of the brick contained a high amount of accessory constituents such as zircon, pyroxene, garnet and amphibole. In addition to several lithic fragments of various igneous and siliceous rocks such as; chert and micro-granite, fig. (5-b). In the all studied samples of bricks, abundant amounts of some none clay minerals such
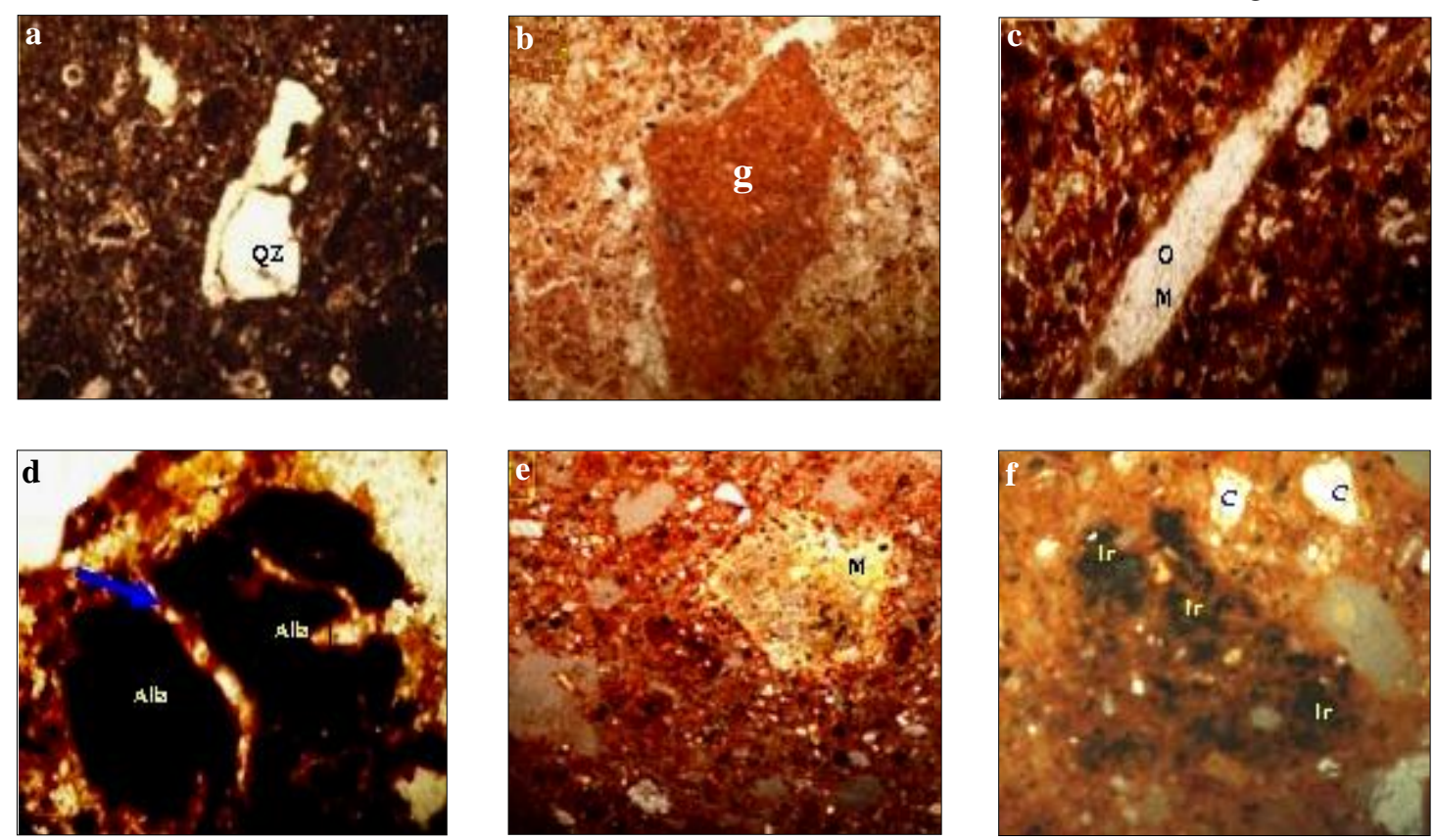

Figure (5) Shows petrographic micrographs of weathered redbrick from water wells at Karnak temple; by PM (40-X) $\underline{\mathbf{a}}$. quartz grain in rich ground of iron oxides and clay minerals, $\underline{\mathbf{b}}$. microgranite fragment, $\underline{\mathbf{c}}$. chopped straw, $\underline{\mathbf{d}}$. deformed allanite crystal filling with calcite vein, $\underline{\mathbf{e}}$.

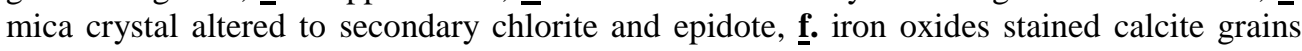
with chocolate brown colors.

\subsection{Morphological features of the samples by SEM}

Some samples of weathered brick were studied by Scanning Electron Microscope (SEM) and have proved that, the brick is highly affected by deterioration mechanisms as follows; The formation of network of cracks and fissures, fig. (6-a) which lead to increase the porosity, loss of strengh and durability of the brick, in addtion to collapse, internal exfoliation and rupture of internal structure of the brick, some of dilated fractures caused the discontinuation and splitting the brick texture and that promoted the penetration water and saline solutions inside the pores of brick, and (by) that means contributes to dissolving and loss of the chemical components. Furthermore migration and wash up of clay nodes, disintegration, eroded 
quartz grains and formation the large voids and cavities in the brick. The SEM micrographs have cleared also that; some fibers and residual organic matters which were added during brick making process for instance, chopped straw, fig. (6-b) resulting from inappropriate firing temperature, these organic materials aid (assist) to the microbiological attack and growth the algal and fungal colonizations which generated a severe damage and degradation of brick originating from the growth of fungal hyphae or the fruiting bodies, fig. (6-c) either on or below the surface and caused dislodging of the various mineralogical grains of the brick and motivate the salty weathering of brick. The SEM investigation has revealed also that;
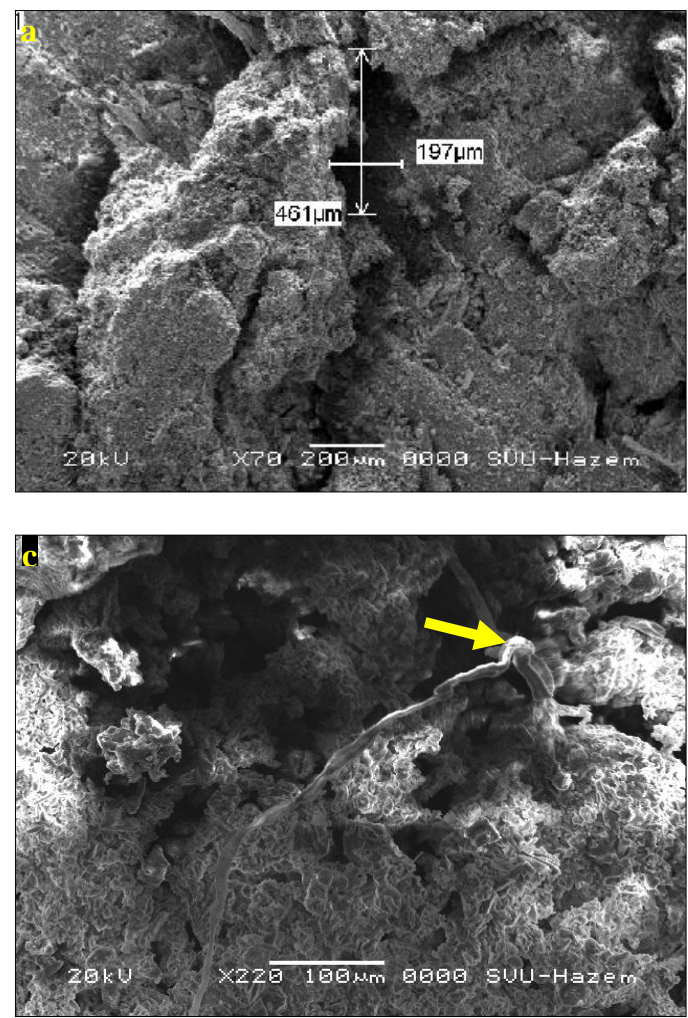

different forms of crystallized salts such as halite and thenardite, fig. (6-d) [according to XRD analysis for the same samples] both are very common salts in a wide range of locations and environments, and extremely destructive and represent aggressive deterioration forms because of its extreme hygroscopic, frequently dissolution and crystallization, hydration and crystallization pressures of that salts which lead to a high degree of volume changes when hydrated, consequently these dangerous salts also cause weakness, destruction, breakdown the brick, disassembling and dislocation of the mineralogical grains as well as dechosion and disintegration of the brick.
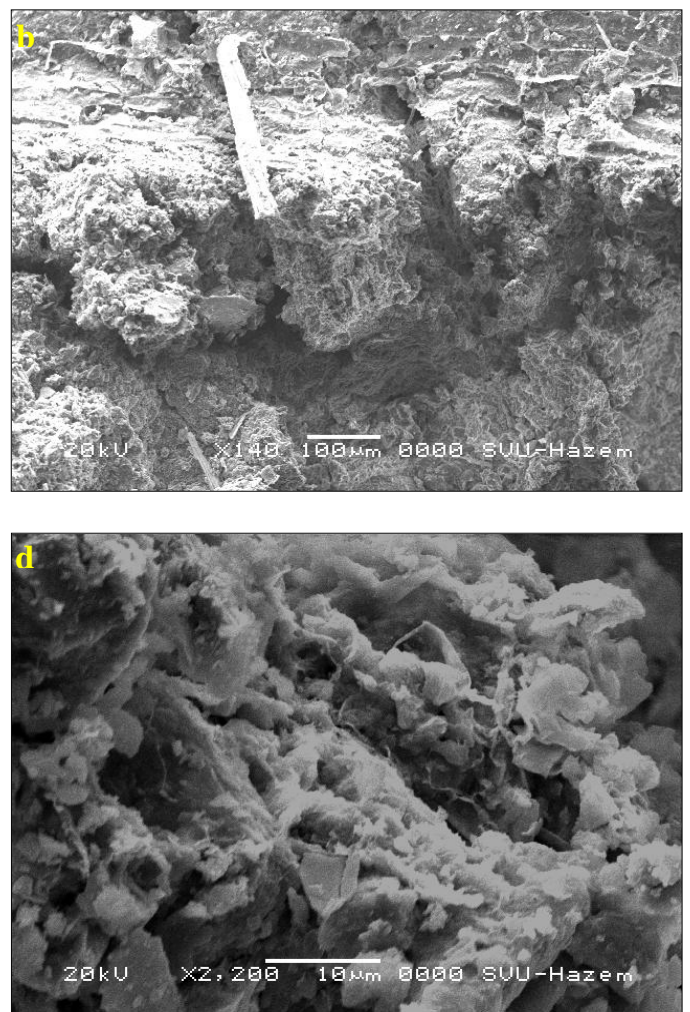

Figure (6) Shows SEM Micrographs of weathered redbrick from water wells at Karnak temple; $\underline{\mathbf{a}}$. cracks and rupture of internal structure, $\underline{\mathbf{b}}$. chopped straw, $\underline{\mathbf{c}}$. the growth of fungal hyphae, $\underline{\mathbf{d}}$. salts of sodium sulfate (thenardite).

\subsection{Analytical results of investigated samples by EDX}

EDX results of brick samples, tab. (1) \& fig. (7) have indicated that the brick is highly weathered by deterioration factors, the elemental order can be put in a decreasing grade according to their concentration as follows: $\mathrm{SiO}_{2}$ (33.90), $\mathrm{Fe}_{2} \mathrm{O}_{3}$ (18.20\%), $\mathrm{Cl}(10.56 \%), \mathrm{SO}_{3}(9.38 \%), \mathrm{Ca}$
$(8.76 \%), \mathrm{K}_{2} \mathrm{O}(5.91 \%), \mathrm{Al}_{2} \mathrm{O}_{3}(5.37 \%)$, $\mathrm{Na}_{2} \mathrm{O}(2.65 \%), \mathrm{TiO}_{2}(2.59 \%), \mathrm{MgO}(1.29 \%)$, $\mathrm{Mn}(0.345 \%)$ in addition to $\mathrm{Cr}, \mathrm{Ni}, \mathrm{Cu}$, $\mathrm{Zn}, \mathrm{Sr}, \mathrm{Y}$ and $\mathrm{Zr}(0.045 \%)$. The obtained results help to understand the deterioration mechanisms affecting the brick used in building water wells at Karnak temples. 
Table (1) EDX microanalysis of weathered red brick of water wells at Karnak temples

\begin{tabular}{ccccccccccccc}
\hline \multirow{2}{*}{ Sample } & \multicolumn{10}{c}{ Analytical Results } \\
\cline { 2 - 13 } & $\mathbf{N a} \boldsymbol{O}$ & $\mathbf{M g O}$ & $\mathbf{A l}_{2} \boldsymbol{O}_{3}$ & $\mathbf{S i O}_{2}$ & $\boldsymbol{P}_{2} \boldsymbol{O}_{5}$ & $\mathbf{S O}_{3}$ & $\boldsymbol{C l}$ & $\boldsymbol{K}_{2} \boldsymbol{O}$ & $\mathbf{C a}$ & $\mathbf{T i O}_{2}$ & $\mathbf{M n}$ & $\boldsymbol{F e}$ \\
B & -- & -- & -- & 38.26 & -- & 6.36 & 8.27 & 4.1 & 7.73 & 3.97 & 0.62 & 30.42 \\
$\mathrm{C}$ & -- & 1.34 & 10.92 & 49.50 & 1.12 & --- & -- & 2.83 & 6.89 & 3.30 & 0.49 & 23.33 \\
\hline D & 4.30 & 2.08 & 3.16 & 24.23 & 0.99 & 12.93 & 20.71 & 11.2 & 11.44 & 1.22 & 0.13 & 7.33 \\
\hline
\end{tabular}
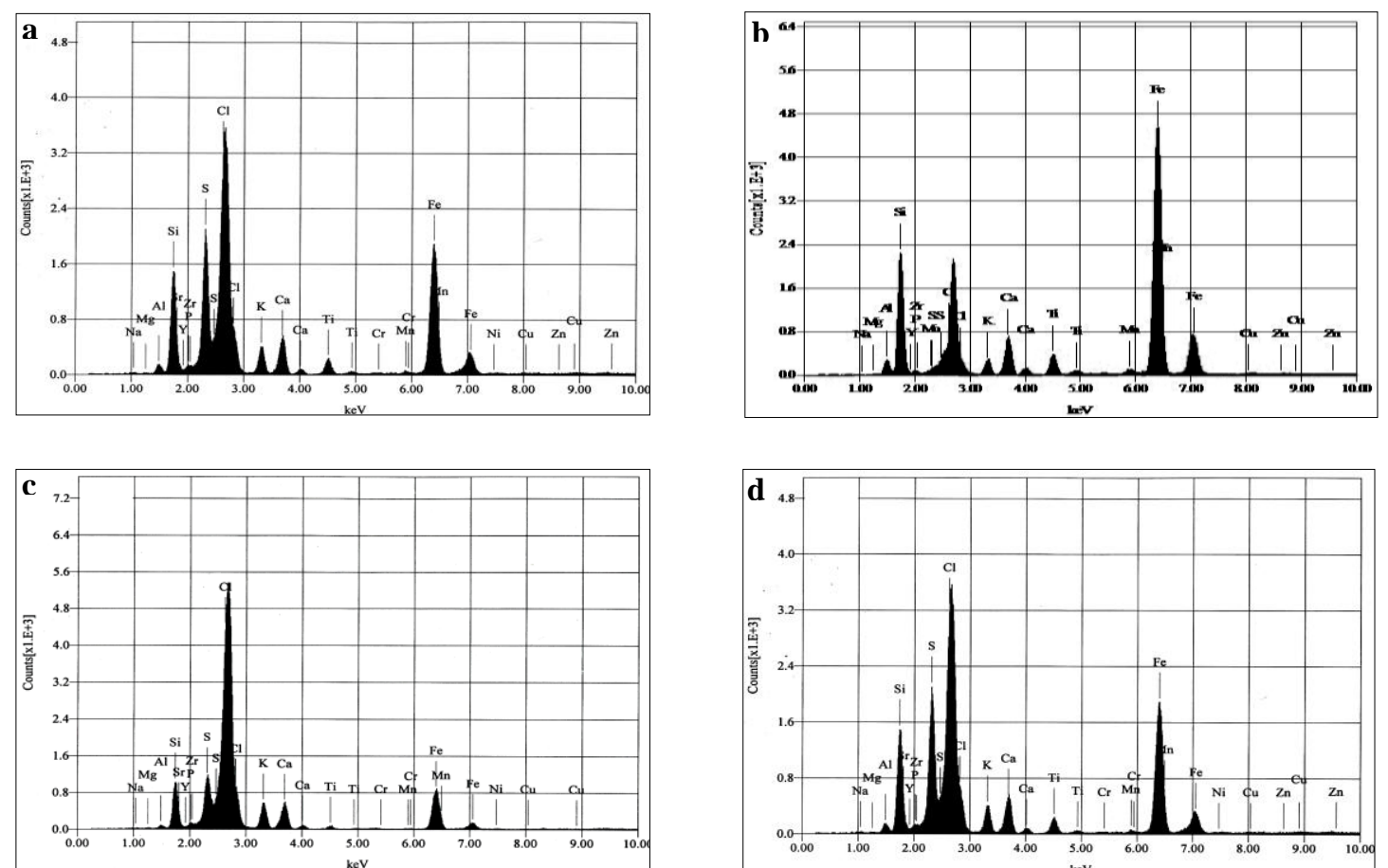

Figure (7) Shows some EDX microanalysis charts of weathered red brick of water wells at Karnak temples.

\subsection{Analytical results of investigated samples by XRD}

The X-ray diffraction analysis (XRD) for weathered samples of brick show that; the bricks suffer from aggressive damage by salts as shown in tab. (2) \& fig (8). The results of XRD have revealed that, the brick consists of quartz $\mathrm{SiO}_{2}$ and

plagioclase feldspar (albite $\mathrm{Na} \mathrm{Al} \mathrm{Si}_{3} \mathrm{O}_{8}$ ) as main components in clay. In addition to sodium chloride (halite $\mathrm{NaCl}$ ) and sodium sulfate or (thenardite $\mathrm{Na}_{2} \mathrm{SO}_{4}$ ) as deterioration or weathering products.

Table (2) XRD of weathered red brick used in water wells at Karnak temples.

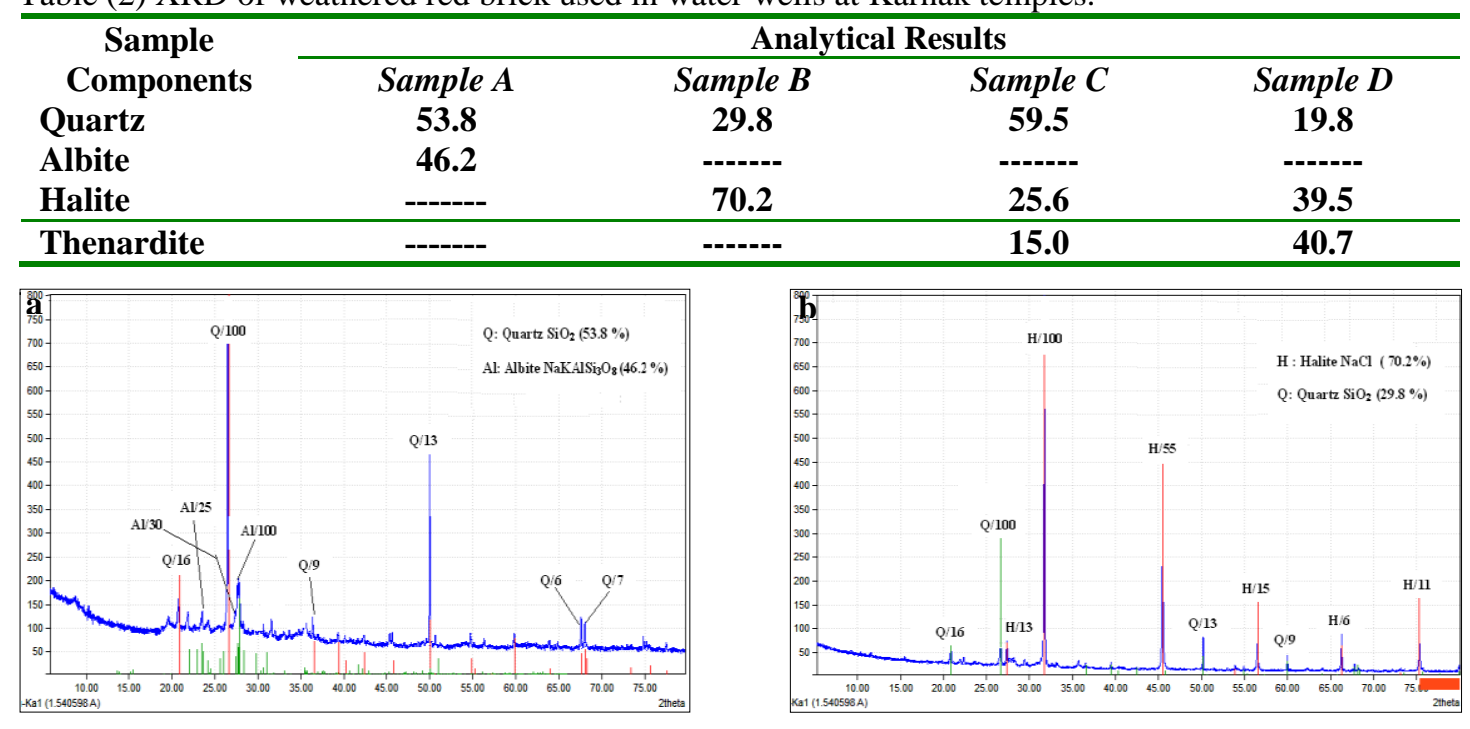



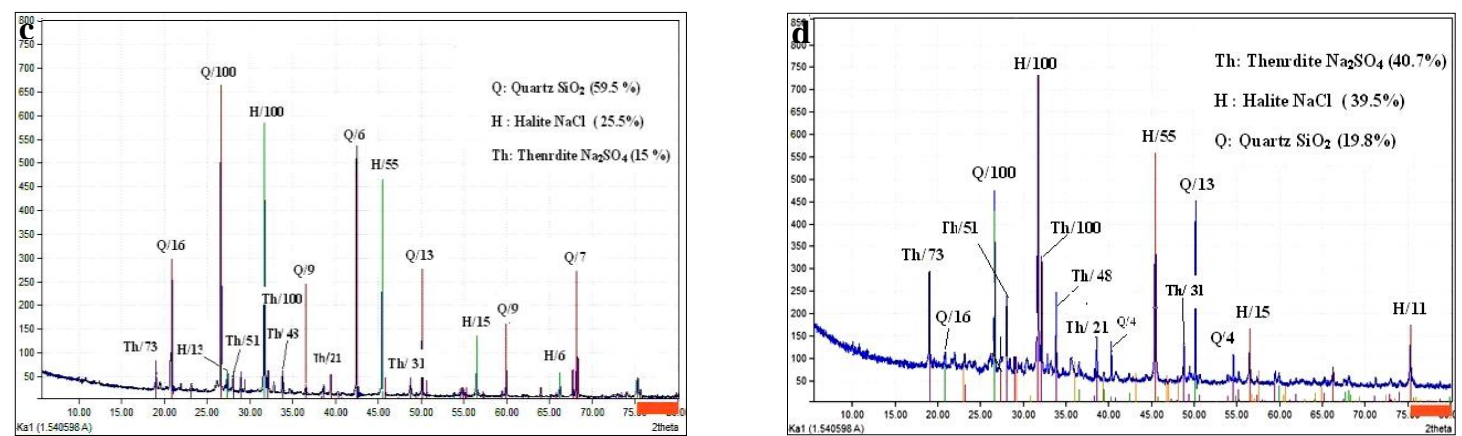

Figure (8) Shows some XRD patterns of weathered red brick of water wells at Karnak temples.

\section{Discussion}

Through analyzing the previous data it could be noted that visual examination by scientific digital camera, fig. (3) has cleared that, the brick samples of water wells at Karnak temples contain different textures range from fine grains (silt) to very coarse (sand) due to the variation of the materials of raw clay used in making that brick which include pottery shreds, red brick fragments, chert pebbles, the color of brick is also varied greatly between light, yellow, reddish, to brown and black due to the variations of firing temperature, and the placing of the brick units in the kiln [19] in addition, the color is an indicator of the type of soil used. LOM investigation, fig. (4) has illustrated that, the brick contains some components which were added during manufacturing process such as; pottery shreds, limestone and red brick fragments, moreover organic materials such as; chopped straw (hay) and animals dung, the presence of these materials in the structure after firing the brick considers as the manufacture defects and indicate that; the red brick was fired in low temperature [20]. The LOM investigation also has revealed that, the samples suffer from several deterioration aspects such as; large holes, deep voids, fissures, cracks and fractures, all the previous highly affected on the physical status of the brick. Furthermore, the petrographic study, fig. (5) has revealed that, the brick samples contain both inorganic and organic materials as follows: The inorganic materials represented mainly in quartz, feldspar, mica, allanite, zircon, iron oxide and rock debris as original constituents. Sericite, chlorite and epidote are secondary constituents due to many alteration processes. Pottery fragments and chopped straw as additional components. All the used materials are related to the local Egyptian environment in-situ which had been used from the long time both in mud, red brick and pottery manufacture. The existence of different rock debris in the brick constituents due to the fact that, the ancient Egyptian made the bricks from the Nile clay deposited through the millions of years of floods. The flood carried these deposits through its journey from the heart continent of Africa along the Nile River in Egypt, which is carved in different rocks loaded with fragments of these rocks and some metals with high hardness and resistance to transport factors. The petrographical investigation of studied samples has shown that, the deterioration features are deformed and cracked allanite crystal filling with calcite vein, as well as the alteration of mica minerals (biotite) to chlorite and epidote, furthermore the iron oxides stained most of the mineral grains in the brick with reddish and chocolate brown colors. On the other hand the presence of cracked limestone fragments indicated that, the brick was fired in a low temperature [21]. Within the same context, SEM studies presented in fig. (6) have proved that, the brick is highly affected by deterioration mechanisms as follows; the brick contains some plant fibers, residual organic matters and chopped straw which were added 
during brick making process, and the brick fired in unsufficient firing temperature,the presence of these matters in brick's structure play an influential role in the deterioration process through assistance the microbiological invasion [22] and growth the algal and fungal colonizations, which depend on the organic matters in the brick in their feeding, the growth of such microorganisms on the brick depends on environmental conditions and the physicochemical properties of the material (the intrinsic properties) $[23,24]$. These microorganisms generated a severe damage and caused degradation of the brick by multiple mechanisms resulting in loss of strength, durability such as; dislodging the mineralogical grains, cracking and disintegrated the structure [25] and motivate the salty weathering of the brick.The penetration of saline solutions from groundwater through the cracks leading to the salts crystalization [26,27] when the environmental conditions are available especially the extreme temperature, the source of water (from ground water and closeness to river Nile) and the salinity of soil in the site. The crystallized salts such as; halite and thenardite caused aggressive deterioration forms such as; destruction, crumbling of the brick, disassembling and dislocation of the mineralogical grains as well as dechosion and disintegration of the brick due to high degree of volume changes from thier crystallization and hydration pressures $[28,29]$. On the other hand the coefficient of volumetric expansion of halite is three times higher than quartz [30]. In addition it could be asserted that elemental analytical results by EDX, tab. (1) \& fig. (7) have revealed that, the brick contains quartz $\left(\mathrm{SiO}_{2}\right)$ as major element in clay. The high concentration of iron oxides $\left(\mathrm{Fe}_{2} \mathrm{O}_{3}\right)$ is natural colorants of Nile clay used in manufacturing the brick giving it a reddish coloring. The high conc-entration of chlorine $(\mathrm{Cl})$ with sodium $\left(\mathrm{Na}_{2} \mathrm{O}\right)$ attributed to the crystalllization of sodium chloride (halite) salt. On the other hand, the high percent of sulfates $\left(\mathrm{SO}_{3}\right)$ is the most common compounds of the soluble salts and/or due to the deterioration of lime mortar with sodium ions to form thenardite $\left(\mathrm{Na}_{2} \mathrm{SO}_{4}\right.$ according to XRD analysis). More than that, the high concentration of calcium oxide $(\mathrm{CaO})$ in all red brick samples attribute to the limestone or carbonates which were used in making red brick, and it is indicate that, the brick was burnt in low firing degrees, and/or may be due to the contamination by lime mortar [31] which was used in the construction of the water wells at Karnak temples. In addition to the presence of alumina $\left(\mathrm{Al}_{2} \mathrm{O}_{3}\right)$ that constitutes the base elements of clay. Also, small quantities of the other oxides such as; potassium $\left(\mathrm{K}_{2} \mathrm{O}\right)$, magnesium $(\mathrm{MgO})$ oxides respectively are correlated with the content of alumina or alteration processes, the potassium is most readily fixed in clay mineral [32]. The amount of titanium oxide $\left(\mathrm{TiO}_{2}\right)$ is natural colorant of clay brick, giving a characteristic yellowish coloring for the bricks. Finally, XRD results, tab. (2) \& fig. (8) have revealed that, the brick mainly consists of quartz $\mathrm{SiO}_{2}$ and plagioclase (albite, $\mathrm{Na} \mathrm{Al} \mathrm{Si}_{3} \mathrm{O}_{8}$ ) as the main components in clay. Most of the samples contained sodium chloride $\mathrm{NaCl}$, may be attribute to the saline solutions from groundwater, and sodium sulfate or thenardite $\left(\mathrm{Na}_{2} \mathrm{SO}_{4}\right)$ which the most probably in the present study precipitated directly from a saturated sodium sulfate solutions (at room temperature $20^{\circ} \mathrm{C}$ ), with decreasing relative humidity, and increasing evaporation rate [33]. On the other hand in specific cases thenardite, correlated with the formation of sulfuric acid $\mathrm{H}_{2} \mathrm{SO}_{4}$ which reacted with sodium chloride to form thenardite $\left(\mathrm{Na}_{2} \mathrm{SO}_{4}\right)$ according to [34] in accordance with the following equation:

$$
\begin{array}{ll}
2 \mathrm{NaCl}+\mathrm{H}_{2} \mathrm{SO}_{4} \longrightarrow \mathrm{Na}_{2} \mathrm{SO}_{4}+2 \mathrm{HCl} \\
\text { Halite } \quad \text { Pollutants } & \text { Thenardite }
\end{array}
$$


Thenardite may be transformed from water free stage $\left(\mathrm{Na}_{2} \mathrm{SO}_{4}\right)$ to the hydrated phase mirabillite $\left(\mathrm{Na}_{2} \mathrm{SO}_{4} \cdot 10 \mathrm{H}_{2} \mathrm{O}\right)$ and that may be cause increasing the volume between $70-250 \%$ [34] and/or reach to $308 \%$ [35] this change in the volume leads to the creation of severe damage such as; fractures, crumbling, disintegration in addition to salts crystallization, the salt

\section{Recommendations}

Field observations and lab analyses have cleared that the brick used in water wells at Karnak temples suffer from many deterioration factors and their features. Therefore, the wells need to different treatments and conservation processes, such as:

* Performance archaeological studies on that wells to determine their historical periods.

* Mechanical cleaning and complete the excavations to remove debris from inside the wells.

* Cleaning and removal of vegetation, weeds and grass from inside and outside that wells.

* Periodically mechanical cleaning of crystallized salts on the surfaces of the brick, during the lack of water and/ or during the dryness periods.

* Restoration and completion of the missing parts from the wells using a suitable brick blocks and mortar of natural lime.

* Consolidation weak brick units using appropriate water-repellent materials or with Ethyl Silicate (TEOS) which gave a significant improvement for the physico-mechanical properties of the red brick [37] and provide an efficient protection against sodium sulfates [38].

* Decoding and re-installation of some fragmented brick blocks using appro- damage for brick depends on the type of salt, the condition of the building, including its porous structure and the cohesive strength of the material [36]. The contamination of brick with these destructive soluble salts bears a considerable risk for the preservation.

priate materials (Araldite or Epoxy resins).

* Mechanical removal of dry biological colonies from the bricks and using chemical pesticides for future resistance and prevent their growth in the future.

* Use nanotechnology and treatment with Titanium oxide $\left(\mathrm{TiO}_{2}\right)$ nano-coating to prevent the growth of micro-algal and microorganisms on the red brick [39] and this treatment leads to improve the preservation of the physical and mechanical properties and the maintenance of aesthetic features of ancient brick with low costs [40] and allows the selfcleaning action of substrata.

* Periodical and continuous monitoring the status of water wells to observe any changes in their conditions.

* Removal of soluble salts by appropriate techniques; mechanical cleaning with brushing and scalpels or using a suitable poultice; sepollite clay, or any other appropriate poultices.

* Establishing interpretive signs and signboards on wells for the clarification of their historical and archaeological importance, also low fencing and barriers around that wells as protective procedures.

\section{Conclusions}

This paper concludes that red brick was the main material for construction water wells at Karnak temples. Through field observation, lab examinations and chemical analyses have revealed that, the brick was subjected to several deterioration factors (physical, chemical, biological and anthropogenic) in addition to its chemical composition and physical properties, on the other hand the function (type of building use) of these water wells also all play an important role in the deterioration process of the brick. In addition, the main deterioration mechanisms were salts crystallization, hard crusts, crumbling disintegration, in addition to 
cracks, fractures, loss strength and aesthetic disfigurement. Furthermore, visual examination of brick samples has revealed that, it has different textures and colours due to the mineralogical components and the firing temperature. Moreover, LOM examination has proved that, the brick contained some organic matters such as; chopped straw and animal dung which were added during brick making and the brick firing in low temperature, which is considered the main intrinsic deterioration factor (manufacture defects). Within the same context, XRF and XRD analyses have displayed that, the brick suffers from the severe damage of the salts especially thenardite and halite. SEM investigation has revealed that, the brick contains organic matters, network of cracks, fractures, cavities in addition to the growth of algal, fungal hyphae and salt crystals which caused decrease the stiffness, durability and accelerated the weathering of the brick.

\section{Acknowledgments}

My deepest appreciation and gratitude to Dr. Mahmoud, A., Assoc. Prof. of geology and U-ores in Nuclear Materials Authority (NMA), who helped and reviewed the petrographic side in the paper.

\section{References}

[1] Blyth, E., (2006). Karnak: Evolution of a temple, Routledge, London.

[2] Boraik, M., Matthieu, M., Abdel-Hafez, S., Ali, M., El-Masekh, S. \& Mahmoud, A., (2010). Geomorphological investigations in the western part of the Karnak temple (quay and ancient harbour): First results, Cahiers de Karnak, Vol. 13, pp: 101-109.

[3] Franzmeier, H., (2007). A Ramesside well at Samana near Qantir-A new insight into the hydrological technology of Pharaonic Egypt, Studia Aegyptiaca, Vol. XVIII, pp: 121-132.

[4] Franzmeier, H., (2007). Wells and cisterns in Pharaonic Egypt: The development of a technology as a progress of adaptation to environmental situations and consumers' demands, in: Griffin, K. (ed), Current Research in Egyptology, Vol. 8 , pp: 37-51

[5] Boraik, M., (2010). Excavations of the quays and the embankment in front of Karnak temples, Preliminary report, Cahiers de Karnak, Vol. 13, pp: 65-78.

[6] Bell, P., (2008). Early bricks and brickwork in South Australia. Department of Environment and Natural Resources, Australia

[7] Van Balen, K., Mateus, J., Binda, L., Baronio, G., Van Hees, R., Naldini, S., Van der Klugte, L., Franke, L., Ferrieri, D. \& Carrara, E., (1999). Expert system for the evaluation of the deterioration of ancient brick structures, Research report, Science, Research and Development, EU publications, Belgium, $159 \mathrm{p}$.

[8] Spencer, A., (1979). Brick architecture in ancient Egypt, Aris \& Phillips Ltd. Warminster, Wilts, England.
[9] de Garis Davies, N., (1943). Paintings from the tomb of Rekh-mi-Re' at Thebes, Publications of the Metropolitan Museum of Art, Egyptian Expedition 11., Plantin Press, NY.

[10] Abd El-Hady, M \& Abd El Hafez, A., (2012). Physio-chemical and mechanical deterioration of monumental mud brick in Egypt, EJARS, Vol. 2 (2), pp: 103107.

[11] Morgenstein, M. \& Redmount, A., (1998). Mud brick typology, sources, and sedimentological composition: A case study from tell El-Muqdam, Egyptian delta, J. of the American Research Center in Egypt, Vol. 35, pp: 129-146.

[12] Cultrone, G, De La Torre M., Sebastián, E., Cazalla, O. \& Rodríguez-Navarro, C., (2000). Behavior of brick samples in aggressive environments. Water, Air, and Soil Pollution, Vol. 119, pp: 191-207.

[13]Lourenço, P., Van Hees, R., Fernandes, F. \& Lubelli, B., (2014). Characterization and damage of brick masonry, in: Costa A., Guedes J. \& Varum H. (eds.), Structural Rehabilitation of Old: Buildings, Building Pathology and Rehabilitation Vol. 2, pp: 109-130.

[14] Gohary, M. \& Al-Shorman, A. The impact of the climatic conditions on the decaying of Jordanian basalt: Exfoliation as a major deterioration symptom, MAA, Vol. 10 (1), pp: 143-158.

[15] Randall E., Hughes, R. \& Bargh, B., (1982). The weathering of brick: Causes, assessment and measurement, A Report of the Joint Agreement between the U.S. Geological Survey and the Illinois State Geological Survey, 92 p. 
[16] López-Arce, P., García-Guinea, J., Gracia M. \& Obis, J., (2003). Bricks in historical buildings of Toledo City: Characterization and restoration, Materials Characterization, Vol. 50, pp: 59-68.

[17] El-Midany, A. \& Mahmoud, H., (2015). Mineralogical, physical and chemical characteristics of historic brick-made structures, Mineralogy and Petrology, Vol. 109, pp: 733-739.

[18] Cultrone, G., Sidraba, I. \& Sebastian, E., (2005). Mineralogical and physical characterization of the bricks used in the construction of the (Triangul Bastion), Riga (Latvia), Applied Clay Science, Vol. 28, pp: 297-308.

[19] El-Gohary, M. \& Al-Naddaf, M., (2009). Characterization of bricks used in the external casing of Roman bath walls "Gadara-Jordan", $M A A$, Vol. 9 (2), pp: 29-46.

[20] Aramide, F., (2012). Effect of firing temperature on mechanical properties of fired masonry bricks produced from Ipetumodu clay, Leonardo Journal of Sciences, Vol. 21, pp: 70-82.

[21] Cultrone, G., Sebastian, E., Elert, K., de la Torre, M., Cazalla, O. \& RodriguezNavarro, C., (2004). Influence of mineralogy and firing temperature on the porosity of bricks, $J$. of the European Ceramic Society, Vol. 24, pp: 547-564.

[22] Kumar, R. \& Kumar, A., (1999). Biodeterioration of stone in tropical environments. The Getty Conservation Institute, NY.

[23] Crispim, C. \& Gaylarde, C., (2005). Cyanobacteria and bio-deterioration of cultural heritage: A review, Microbial Ecology, Vol. 49, Springer Science+Business Media, Inc, Germany.

[24] Miller, A., Sanmartín, P., Pereira-Pardo, L., Dionísio, A., Saiz-Jimenez, C., Macedo, M. \& Prieto, B., (2012). Bioreceptivity of building stones: A review, Science of the Total Environment, Vol. 426, pp: 1-12.

[25] Gomez-Alarcon, G. \& de La Torre, A. (1994). The effect of filamentous fungi on stone monuments: the Spanish experience. In: Singh, J. (ed.), Building Mycology. Management of Decay and Health in Buildings, Chapman and Hall, UK, pp: 295-309.
[26] Alves, C., Amalia , M. \& Hammecker, C., (1996). Water transfer \& decay of granitic stones in monuments, Comptes Rendus de l' Académie des Sciences, Vol. 323 (5), pp: 397-402

[27] Grassegger, G., (1999). Decay mechanisms of natural building stones on monuments: A review of the latest theories, Werkstoffe und Werkstoffprufung Im Bauwesen, Stuttgart.

[28] Scherer, G., (2000). Stress from crystallization of salts in pores, in: Fassina, V. (ed.) $9^{\text {th }}$ Int. Cong. on Deterioration \& Conservation of Stone, Venice, Elsevier, pp. 187-194.

[29] Bionda, D., (2004). Salt deterioration \& microclimate in historical buildings. Institute fur Denkmalpflege, Forschungsstelle Technologie und Konservierung, ETH Zurich, 10 p.

[30] Kwaad, F., (1970). Experiments on the granular disintegration of granite by salt action, from field to laboratory, Publicate, No. 16, pp.67-80.

[31] Fernandes, F., Lourenço, B. \& Castro, F., (2010). Ancient clay bricks: Manufacture and properties, in: Bostenaru Dan, M., Přikryl, R. \& Török, Á. (eds.), Materials, Technologies and Practice in Historic Heritage Structures, Springer Science+ Business Media B.V. pp: 29-48

[32] Pettijohn, F., (1963). Chemical composition of sandstones-Excluding carbonate and volcanic sands, $\mathrm{Ch} \mathrm{S}$, in: Fleischer, M. (ed.) Data of Geochemistry, $6^{\text {th }}$ ed., Geological Survey Professional, No. 440, Washington, pp: S1-S21.

[33] Rodriguez-Navarro, C., Doehne, E. \& Sebastian, E., (2000). How does sodium sulfate crystallize? implications for the decay and testing of building materials, Cement and Concrete Research, Vol. 30, pp: 1527-1534.

[34]El-Gohary, M., (2011). Chemical deterioration of Egyptian limestone affected by saline water, IJCS, Vol. 2 (1), pp: 17-28.

[35] Shoulikidis, Th., (1991). The effect of pollution on stones: The Acropolis experience, in: Ambrosi, L. \& Zezza, F. (eds.), Weathering and Air Pollution, Venezia, pp.243-272. 
[36] Young, D., (2008). Salt attack and rising damp: A guide to salt damp in historic and older buildings. Heritage Council of NSW; Heritage Victoria.

[37] Franzoni, E., Pigino, B., Leemann, A., Lura, P., (2014). Use of TEOS for firedclay bricks consolidation, Materials and Structures, Vol. 47 (7), pp: 1175-1184.

[38] Franzoni, E., Sassoni, E., Graziani, G. \& Fregni, A., (2014). Consolidation of firedclay bricks by ethyl silicate: durability to salt crystallization, in: De Clercq, $\mathrm{H}$. (ed.) $3^{\text {rd }}$ Int. Conf. on Salt Weathering of Buildings and Stone Sculptures (SWBSS2014), Brussels, pp: 347-356.
[39] Graziani, L., Quagliarini,E., Osimani, A., Aquilanti, L., Clementi, F., Yéprémian, C., Lariccia, V., Amoroso, S. \& D’Orazio, M., (2013). Evaluation of inhibitory effect of $\mathrm{TiO}_{2}$ nanocoatings against microalgal growth on clay brick façades under weak UV exposure conditions, Building and Environment, Vol. 64, pp: 38-45.

[40] Graziani, L. \& D’Orazio, M., (2015). Biofouling prevention of ancient brick surfaces by $\mathrm{TiO}_{2}$ - based nano-coatings. Coatings, Vol. 5, pp: 357-365. 